\title{
Georg Wickram - the Author Censoring Himself [1]
}

\section{Av Elisabeth Wåghäll, universitetslektor i tyska}

\author{
Länk till presentation av Elisabeth Wåghäll
}

The German author Georg Wickram of Colmar, Alsace, lived in the first half of the sixteenth century. He was the illegitimate child of the wealthy burgher Konrad Wickram: his mother is not known by name. His illegitimacy may have been the reason why Wickram never received a scholarly education. Being born out of wedlock meant that he was excluded from many rights he otherwise would have had as the son of a patrician and also that he never could follow in his father's footsteps. He spent most of his life in the area around Strasbourg, working as a city clerk and writing prose novels, plays and didactic texts. He did not receive citizenship in Colmar until 1546 when he inherited a house from his father.

All of Wickram's writings are in the vernacular, the themes are simple and straightforward. Love, friendship, education and family life were topics of interest to the humanists as well as to the German reformers; Wickram discussed these topics in all his works, yet he did it without any overt comments on the political, economical or religious developments of his time. He at first sight seems to neither approve nor disapprove of events such as the Reformation or the peasant's war; he simply tells about relationships. He privatizes the real world, making it conform to his idealistic fictional world. Wickram turns inward; he stresses honesty, obedience, education and fear of God. Several characters in his works rise in society because of their virtue and their ability to conform to the social rules of conduct. A reason for this fear of being different (often referred to as "otherness") might be found in Wickram's inferior social status. We can assume that he, as an insignificant city clerk, refrained from writing about topics which might upset the city magistrate or the citizens of Colmar. It is my intention, by a closer look at Wickram's works, to show how Wickram avoids confrontations with controversial matters, how he strives to conform out of fearing disorder, and how he tries to establish peace with the world around him.

Most obvious is Wickram's fear of controversy in matters regarding religion. Living in Alsace, the reformation movements definitely did not pass by Wickram unnoticed, but he rarely discusses or mentions the religious changes occurring in the 16th century. Wickram writes so carefully that one can assume that he is trying to avoid topics that otherwise would upset the reader or the publisher. He often mentions the importance of godfearing citizens but he is never specific in his suggestions, nor is he polemical. Martin Luther and the humanist Erasmus of Rotterdam are the only two historical figures of the time that Wickram mentions; Erasmus is praised as a "very learned man," whose name never will be forgotten,[2] while Martin Luther is mentioned incidentally in a surprisingly negative tone.[3] Robert H. Murray once stated: "Luther was so anxious for progress that he sometimes forgot order. Erasmus was so anxious for order that he sometimes forgot progress."[4] This is probably why Wickram preferred Erasmus over Luther. No other reformer is mentioned anywhere in Wickram's works, even though one could expect that Martin Bucer, a prominent figure in the Strasbourg reform movement, was well known by Wickram. Wickram often in his texts gives examples of different ways of living, similar to suggestions made by Bucer. Wickram's works were printed in Strasbourg, and it was the only city he frequently visited. Wickram and Bucer also have an equally strong belief in the family as the smallest and most important unit in society. The fact that the Reformation was not accepted in Colmar until 1575 might be the reason for Wickram's hesitation to openly show where he stood in issues regarding the Reformation. Only indirectly--in his 
descriptions of everyday life--is it possible to see that Wickram seemed to approve of many of the ideals of the reformers.

Wickram shares this interest in the private sphere with many other authors and intellectuals of the 16th century, who were increasingly aware of some of the changes taking place in society. Philippe Ariès has pointed out some of these changes, which are focused more on the individual than on society as a whole: "... the changes can be classed under six heads: manners, which promoted a new set of attitudes toward the body; self-knowledge, gained through private writing; solitude, prized not only for its ascetic value, but as a kind of pleasure; friendship, cultivated in private; taste valued as a means of self-representation; and convenience, the result of improvements on daily living."[5]

The changes can be seen in all of Wickram's texts. Wickram concentrates on private life, but does not accept any changes that will cause conflict with existing, traditional values. Not even within a closed circle of family members does he allow non-conformity. In the following I will give some examples of this topic of inwardness and isolation in Wickram's works.

In his first prose novel Galmy Wickram portrays a young knight at a duke's court (in Brittany), who falls in love with the duchess. In the courtly literature of the Middle Ages the love of a socially superior lady was not unusual; to Wickram love relationships - sexual or spiritual - are impossible if they cannot be legitimized through marriage, i.e. by society, especially if the relationship does not remain a secret between the lovers. Wickram seems to come to the conclusion that love that is kept secret cannot threaten anyone. The problem then, is to keep the love secret, which, as it turns out, is an almost impossible task.

In Galmy the duchess tries to defend her love to Galmy as the love of a sister to a brother. Her marriage to the duke is described as very happy throughout the book, despite the problems she has to go through. The love between Galmy and the duchess never is physical; not a single kiss is exchanged. It is true love without any passion. "The knight often looked delighted at the dutchess/ [he] would have liked to talk to her/ but both of them avoided this because of their irreproachable behavior" (Galmy 51). This, however, is not enough for Wickram. After Galmy's interest in the duchess is discovered, he has to leave the court for as long as the duke and duchess are married. The problem is that Wickram wants Galmy and the duchess to be a couple; Galmy saves her life, and his superior qualities as a knight make him equal to the duchess on a moral level. On the other hand Wickram would never consider adultery as a solution to the problem. Instead the duke must die; he is struck by a life-threatening illness.[6] Galmy cannot return to the court until he gets a message about the duke's death; this message is the cue for the happy ending of the book. Galmy's reward is not "minne" but marriage (226). He soon takes over the position of the duke and order is reestablished. No adultery has officially been committed, the duchess is not left to rule the country without a husband and Galmy has been properly rewarded. Even though Wickram lets a man of lower nobility marry a duchess, the order has not been disrupted; Galmy's moral virtues make him well suited for his future tasks. He never revolts against the system and throughout the book he is very aware of his (social) inferiority.

Gabriotto and Reinhart shows the same problem from a different point of view. Again action takes place at the court. Two virtuous young men of lower nobility fall in love with women of a higher social class; one of the women is the sister of the king of England, the other her best friend. In the beginning of the book Wickram shows how unpredictable love is and that it, like "Fortuna" or destiny, is impossible to resist. Love hits suddenly in Wickram's works; the characters cannot control their feelings and therefore not avoid conflict - neither morally within themselves, nor with society. The problem in Gabriotto and Reinhart is that the main characters are very young. They are acting without permission of the parents or guardians, i.e. they are disobedient, which, in this text is a mortal sin. Their love is a threat not only to the parents but also to society as a whole because of their differences in social rank. Wickram's conclusion seems to be that disobedience towards 
parents result in disorder at best, anarchy at worst.

In his works Wickram often avoids this problem by not mentioning the parents or by separating the children from their parents. It is not until his last prose novel that we encounter what we today would call a nuclear family consisting of father, mother and children. In Wickram's earlier works the children/ young adults are more often represented by guardians, who have less control over the children than parents do. In Gabriotto and Reinhart the king is acting on behalf of his sister and her friend and Gabriotto's old and not very authoritative father is responisble for Gabriotto as well as Reinhart. It is as if Wickram tries to show that a "real" family would prevent the problems he is describing from happening.

When the main characters fall in love with each other, they all agree that the relationships have to be kept secret because of the young men's lower social status. Needless to say, this is not possible, especially not after the couples secretly marry. The king first finds out about Reinhart's love to Rosamunda and then Gabriotto's love to Philomena and he is outraged. It does not matter to him that Gabriotto and Reinhart are the bravest knights at his court; they are still socially inferior to the girls.

The story from this point on takes many turns. The young men have to leave England, they come back, but Gabriotto soon is forced to leave again. He dies while gone this second time - his heart breaks of sorrow when he cannot be together with Philomena. Philomena dies of a broken heart when she finds out about Gabriotto's death. The other two young people soon follow them.

In the text Wickram clearly emphasizes the cruel manner of the king and the problems that occur when people of different social rank fall in love with each other. At the same time he is incapable of portraying relationships that do not conform with traditional values. JanDirk Müller has stated: "Violence, conspiracy, attempted assassination makes the reader believe that the lovers are 'in the right'. But this is not absolutely true."[7] Müller comes to the conclusion, "that the passion acts as a threat upon social instituions." Wickram therefore has to bring the love relationships to an end. All the main characters have to die. This at first seems like a very drastic solution, but two explanations can be given for this incident. First of all the characters have to be equally punished. They acted against the conventional political, religious, and social rules, something Wickram cannot accept. Secondly, Wickram still seems to regard the relationships as ideal. He therefore does not want the couples to be apart. Their love cannot be destroyed as described by Wickram - it is determined by fate and the characters have no power over their own feelings. Wickram on the one hand is afraid of any change of order and, on the other hand, he wants to show that nothing can destroy real, virtuous love. Death therefore is no obstacle for the love between the young lovers, and in death they are able to meet again. Wickram here clearly argues against injustice but his fear of disorder prevents him from proposing changes in society.

In Manual For Young Boys we find a similar pattern - one has to comply with the rules given by the authorities or perish. This text does not describe love relationships but different kinds of friendships. The noble boy Wilbald's life gets very troublesome when he is befriended by a butcher's son Lothar. Neither one of the two boys listens to his parents. They steal, lie, drink and gamble. They finally have to leave their home town after Wilbald has hurt his school-master with a knife. Their lifestyle does not change in any way after they leave their home town in Prussia. They continue living their lives in a way that only leads to poverty and ultimately to death. Lothar never changes; he cannot think of any other way to support himself than through theft. If he wants something he takes it, but one day he is caught and prosecuted. He has to pay for his sins with his life. Wilbald, on the other hand, at this point has come to realize that his life will have to change. After he and Lothar decide to go separate ways, Wilbald slowly comes to the conclusion that he has to work hard and to turn to God for forgivness in order to survive. 
In this work Wickram again shows that the outsiders of society have no chance to survive as such. Lothar, who refuses to obey parents and authorities dies, and Wilbald, who regrets his earlier lifestyle, is forgiven after he returns to his home town and promises to obey his father and older brother. He himself has, at this point, no rights, just obligations.

Wickram is able to reestablish the order lost with the downfall of the disobedient nobleman Wilbald. Wilbald does not end up in misery, but manages to climb to the position he once lost. He eventually becomes a perfect father and husband and takes over his own father's position at the court. Had Wickram at first claimed that nobility of heart, mind and soul is superior nobility by birth, he at the end of the book takes this statment back. "Thus many a noble mind - given a nobleman by birth - is corrupted by idle company."[8] This can only be seen in the light of Wickram's own position; the previous statements about a nobility of the soul could be seen as a threat by his superiors. Nowhere else can one find similar statements in Wickram's works, and this specific statement is mentioned parenthetically. The book focusses on a different topic: "The focus of Wickram's novel is the strength of the family. Wilbald's disobedience to his parents, his running away, are redeemed by his return and their forgiveness."[9]

Wickram's last novel, Of Good and Bad Neighbors does not show the conflicts of his earlier works. All characters belong to the same social class, the children obey their parents because the parents do not give the children any opportunity to be disobedient. Wickram in this text heavily emphasizes the importance of a good upbringing of future generations. The book is clearly one of Wickram's most moralizing texts. As soon as the parents find out about the aspiring love between their children Amelia and Lasarus Jr. they take precautions to keep the children from getting too involved with one another. What was possible in Wickram's early novels (secret love), where the characters were noble people, is now impossible.

Did Wickram have to be more careful when he described people from his own social class? His "courtly" works contain a certain amount of, in his eyes, morally dubious relationships, but in a story about merchants and other city dwellers, he has to leave out anything that could give the rising urban middle class a bad reputation. "Love" vanishes from the story and "marriage" takes its place; in Of Good and Bad Neighbors love does not really exist until after the weddings. The first marriage described in the book takes place mainly to establish frienship between two of the male characters; the younger man marries the older man's daughter.[10] In the case of Amelia and Lasarus Jr., the parents are able to separate them from each other until they are old enough for marriage. Lasarus Jr. is sent away to foreign countries until he has learned his profession (goldsmith) and is able to support a family. At the end of the book the main characters create their own very small and peaceful community; contact with the outside world is significantly curtailed. The solution for a life in harmony with God is not integration with but withdrawal from society.

After having studied several of Wickram's works, it is possible to say that Wickram in Of Good and Bad Neighbors has "privatized" his topic to such an extent that it loses its connection with reality. Wickram's works show a development away from the public courtly society to the private sphere of the urban middle class family of the 16th century. Wickram often claims that he describes real life situations, but to keep order in a quickly changing society he has to withdraw from it. Every time the reader expects that a rule will be broken, the pendulum swings back and order is reestablished. The topics in Wickram's last two novels are realistic in themselves, but his own fear of change seems to lead only to idealism. Instead of proposing change to improve living conditions, he creates private spheres with little or no connection with the outside world. Wickram seems to desire the ideal, largely troublefree world that was nowhere to be found in sixteenth century German society.

\section{(C) Elisabeth Wåghäll}


[1] Paper given at The Rocky Mountain Medieval and Renaissance Association, April 811, 1993.

[2] Wickram, Georg. Sämtliche Werke. Ed. Hans-Gert Roloff (Berlin: Walter de Gruyter, 1976- ). This quote from Der irr reitend Pilger, Sämtliche Werke VI:88. All translations made by Elisabeth Wåghäll.

[3] Der treue Eckhart, Werke, Eds. Johannes Bolte and Willy Scheel (Tübingen: n.p., 19011906). Stanzas 434-436, 457-460, 824-828.

[4] Robert H. Murray, Erasmus \& Luther. Their Attitude to Toleration (New York: The MacMillan Comp, 1920) 344.

[5] R. Chartier, A History of Private Life. III. Passions of the Renaissance (Cambridge: Harvard up, 1989) 163.

[6] Walther Haug has characterized the relationship between Galmy and the duchess as "inner adultery". Even though the relationship is never sexual, the emotions between the lovers are very strong. Walter Haug, "Jörg Wickrams Ritter Galmy. Die Erzählung des Romans als Ursprung seiner Möglichkeit." Traditionswandel und Traditionsverhalten. Ed. Walter Haug, Burckhart Wachinger (Tübingen: Nieweyer, 1991) 96-120. [7] "Jörg Wickram zu Liebe und Ehe," Wandel der Geschlechterbeziehungen zu Beginn der Neuzeit, Eds. Heide Wunder, Christina Vanja (Frankfurt am Main: Suhrkamp, 1991) 35. [8] ... "dem es doch von natur angeboren ist" (98). See also 15, 42, 60 [9] Miriam Usher Chrisman, Lay Culture, Learned Culture. Books and Social Change in Strasbourg 1480-1599 (New Haven: Yale UP, 1982) 212.

[10] In Wickram's defense he insists on mutual love and agreement between bride and groom. 